\title{
Perceptions of Discriminatory Practices and Attitudes: A Survey of African American Librarians
}

\section{Cynthia Preston}

\begin{abstract}
The perceptions of African American librarians regarding discriminatory practices and attitudes in the workplace and how they influence job satisfaction were the focus of this study. A descriptive survey, including a questionnaire, was used to observe both personal and observed experience of racial discrimination within the profession. Practicing librarians were surveyed for their observations of the situation as it stands today, as well as for their ideas and opinions on issues facing the African American librarian in the future. This study focused on relationships with supervisors, patrons, coworkers, and management.
\end{abstract}

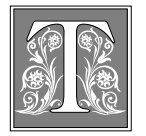

he civil rights movement of the 1960s focused attention on minority groups. The library science profession responded to the changing climate by recruiting minorities, both through scholarships to graduate schools and by establishing "equal opportunity" in hiring library professionals.

Literature on minorities in librarianship expanded in volume during this period, led by the prolific author E. J. Josey. ${ }^{1}$ Josey and others produced a number of monographs that contained essays by black librarians addressing issues and prevailing attitudes that affected them. After the early 1970s, the subject of minorities in librarianship saw little print coverage until the latter 1980s when journal articles began to reflect the frustration felt by African Americans in the field of libraries and information science. Now is an appropriate time to reexamine the attitudes and perceptions of these professionals. Are African American librarians satisfied with their choice of profession? Is the level of job satisfaction felt by African Americans influenced, positively or negatively, by the same factors that affect their nonminority peers?

\section{Review of the Literature}

George P. D'Elia defined job satisfaction as “. . . an employee's affective response to his job environment." ${ }^{2}$ Studies of job satisfaction among professional librarians are well documented in the literature. In a 1986 replication of her original study, Beverly P. Lynch teamed with Jo Ann Verdin to compare differences in the satisfaction levels of professionals and nonprofessionals, males and females, reference and technical service workers, supervisors and nonsupervisors, and new

Cynthia Preston is a Reference/Collection Development Librarian in the Education, Human Ecology, Psychology, and Social Work Library at Ohio State University; e-mail: preston.7@osu.edu. 
and long-term employees. ${ }^{3}$ The results of the second study confirmed those of the original. No significant difference was found between male and female librarians in terms of job satisfaction, but different levels of satisfaction were found between professionals and nonprofessionals and between short- and long-term employees.

\section{Is the level of job satisfaction felt by African Americans influenced, positively or negatively, by the same factors that affect their nonminority peers?}

Susanne P. Wahba's study focused on Maslow's five basic needs in relation to job satisfaction: self-actualization and autonomy, esteem, social, security, and physiological. ${ }^{4}$ One result of her study was that females were less satisfied than males, which does not concur with Lynch's findings showing no significant difference.

Beginning librarians were the focus of D'Elia's study. His goal was to determine which factors contributed to job satisfaction among librarians new to the profession. His analysis supports Lynch's finding of no significant relationship between job satisfaction and gender. The type of library where one was employed also was not relevant. However, supervisory relationships and specific job characteristics proved to be strong determinants of job satisfaction among beginning librarians.

In a study of job satisfaction among U.S. academic librarians, Mohammad Mirfakhrai found that supervisory and coworker relationships, as well as the work itself, had a strong influence on overall satisfaction. ${ }^{5}$ This concurs with D'Elia's findings regarding the importance to librarians of a positive supervisory environment. ${ }^{6}$

Another frequently cited study conducted by William J. Vaughn and J. D. Dunn defined job satisfaction as "the feeling an employee has about his pay, his work, his promotion opportunities, his co-workers and his supervisor." ${ }^{\prime 7}$ The authors assigned a numerical value to each of these factors and then computed a grand total to gauge overall significance. Again, the employee's relationship with his or her supervisor proved to be a very strong determinant of job satisfaction.

One factor not taken into consideration in any of these studies was race. Do racism and discrimination play a stronger role in job satisfaction of African American librarians, or are the major correlates of job satisfaction the same, regardless of race?

The status of African American librarians parallels that of minorities in other professions. Although "equal opportunity" and "affirmative action" were the buzzwords of the 1960s and 1970s, many blacks in the library profession today are disillusioned with the path their careers are taking. Some find themselves reaching mid-level management positions only to find that the "climb up the ladder of success" stops at the middle rung.

At the request of the Harvard Business Review, Edward W. Jones Jr. assessed the progress of black managers in U.S. corporations. The results of his research, though surprising to some, confirms the frustration and anxiety African American professionals face on a daily basis. In his article, Jones coins the term colorism to reflect an attitude that describes a predisposition to act in a certain manner based on the color of a person's skin. ${ }^{8}$ Interviews held with four high-level black executives resulted in the following comments: "aggressive, self-motivated, high-achieving blacks are now feeling deep frustration. Some have left, others stay but are fed up"; "try to conform, and even job hop to other companies, only to confront the same racial barriers-well, it's debilitating"; "old biases, attitudes, and beliefs stack the cards against us." One executive refers to what this author calls the "spook-by-the-door" syndrome-"they want you to be just a number in a seat representing a particular program." 
Perhaps the best way to summarize the findings of Jones's research is to examine a phenomenon he calls "running the gauntlet." This refers to the fine line African American professionals walk as they try to maintain their ethnic identity and at the same time not offend their white peers and business associates. To quote, running the gauntlet means "being smart but not too smart. Being strong but not too strong. Being confident but not egotistical to the point of alienation. Being the butt of prejudice and not being unpleasant or abrasive. Being intelligent but not arrogant. Being honest but not paranoid. Being confident yet modest ...." The whole situation is a Catch-22 where you are "damned if you do and damned if you don't." ${ }^{\prime 10}$ The question one needs to ask is just how this affects the attitudes and job satisfaction of minority librarians and what the consequences are to the library profession.

\section{Administrators may believe that bringing minorities into the workplace under the banner of equal opportunity ends their responsibil- ity to ensure that equality is maintained.}

Most of the current literature on African American librarians deals with recruitment and retention. However, occasional references do occur regarding the status of blacks within the profession. In April 1991, University of California-Irvine library director Calvin Boyer resigned amidst growing controversy that his administration was biased against women and minorities. ${ }^{11}$ A 1988 Seattle Public Library employee task force was charged with examining perceptions concerning retention and treatment of minority staff members found that there were "serious problems," and one conclusion of the task force was that "some employees of color felt they faced discrepancies in hiring and a double standard at work." 12 Even the Library of Congress is not immune from such accusations. In July 1988, a U.S. district judge found in favor of several hundred black employees who were passed over for promotion between 1973 and 1987. ${ }^{13}$

In her essay "Employment Discrimination Faced by Black Librarians," Margaret Collins shared the results of an informal survey of black librarians. ${ }^{14}$ She listed a number of allegations of discrimination within the library community, including:

- number of African Americans in the profession;

- classification of African Americans on the staff;

- denying African American employees benefits that similarly situated white employees received;

- retaliating against African Americans who complain of mistreatment;

- waiting until the evaluation to give negative performance feedback;

- not providing African Americans with the same continuing education opportunities afforded to whites;

- not including African Americans in key meetings and social functions;

- low expectation of African Americans;

- assigning tedious and routine library work to African Americans;

- deliberate unavailability of supervisors to train and share information;

- lack of promotion opportunities for African Americans;

- termination without cause;

- harassment and intimidation of African American employees;

- denying job opportunities because of race.

There are those who feel that affirmative action and other programs have provided a solution to the problem of inequality in the workplace. Not only is the assumption incorrect, but the benefits of such programs are highly debated within the African American community itself. Minorities who feel fortunate to be the beneficiaries of these programs may later 
discover that they are resented by peers who feel they have been "handed" a position based solely on skin tone. Administrators may believe that bringing minorities into the workplace under the banner of equal opportunity ends their responsibility to ensure that equality is maintained. Black employees then have the extra burden of proving to employers that they are qualified to advance within the ranks while assuring their colleagues that they have indeed earned whatever promotions they may receive. One recent article on affirmative action and diversity echoes Jones's gauntlet theory, "for this reason, affirmative action is a red flag to every individual who feels unfairly passed over and a stigma for those who are its beneficiaries." 15

Similar views have been expressed by Patrick Hall. In his article "Against Our Best Interests: An Ambivalent View of Affirmative Action," he reflected on conversations with other minority librarians who shared feelings of self-doubt about their achievements. ${ }^{16}$ "Affirmative action has always placed an asterisk next to them. This is only one of the negative consequences of affirmative action despite the so-called gains. No matter how hard one works, or how many master's or doctoral degrees one possesses, the specialhire asterisk - that small star of omission used to indicate doubtful matter-is ever present."

Although recent literature has begun to focus on job satisfaction and librarianship, little has related directly to minorities. A study by Leigh Estabrook, Chloe Bird, and Frederick L. Gilmore on the effects of automation on job satisfaction found that race is the second largest factor in explaining job satisfaction among professional librarians, with whites being significantly more satisfied than blacks. ${ }^{17}$ The authors of the study felt this was disturbing because it indicated that libraries do not treat minority workers equally.

As an African American student of li- brary and information science with seventeen years of paraprofessional experience, the author has had many conversations with black librarians from all areas of service and faculty rank. Many of their comments and opinions can best be summed up by Hall's article "Yassah! I's the Reference Librarian!" In it, The author reflected that:

... time and time again I am either directly or indirectly snubbed, patronized, or completely ignored by both patrons and my fellow staff members. . . repeatedly, patrons will seek a white librarian to confirm the answers I have given them, even on very simple questions that someone who was 'brain dead' could answer. ... my role as a black librarian is subject to society's notso-subtle bias about the intellectual capacity of blacks. ... after such experiences, blacks in my position can't help but feel somewhat angry and resentful. ... the library establishments for which we work must be cognizant of the special situations minority librarians face in performing our duties—situations that are not faced by our white colleagues. ${ }^{18}$

If the frustration felt by some minority librarians continues at the current level, not only will they be tempted to leave the profession but their experiences may serve to dissuade other minorities from entering the field. This study will evaluate issues concerning black librarians today. It is hoped that it also will aid in the future recruitment and retention of librarians of color.

\section{Objectives}

The purpose of this study was to examine the perceptions of African American librarians on discriminatory practices and behaviors that occur within the profession and to ascertain if these perceptions are stronger indicators of job dissatisfaction 
than those factors identified by nonminority librarians. To this end, it was necessary to reexamine some areas already noted that influence job satisfaction among librarians. These include salary; relationships with coworkers, supervisors, and administrators; area of work; type and size of library; and opportunity for advancement.

By including questions that deal with issues specific to African American librarians, this study attempted to determine whether the practice or perception of racist or discriminatory behavior weighs more heavily in the determination of job satisfaction than those factors not particularly associated with minority groups.

\section{Methodology}

A descriptive mailed survey was used to collect data on both personal and observed perceptions of racial discrimination within the profession. The results were analyzed to see what, if any, relationship these factors have on job satisfaction among African American librarians.

\section{Sample}

The target population to be studied was African Americans employed in libraries in the United States in 1993; however, no single source identified this group in its entirety. The eighth edition of the membership directory of the Black Caucus of the ALA defined an accessible population. Because the majority of members of the Black Caucus hold professional positions, use of the directory further defined the accessible population as predominantly professional, degreed librarians.

Corporations, group members, and retired members were eliminated from the sample. To ensure representation of all library types, the remaining 469 personal members were categorized by type of library (i.e., academic, public, school, and private). As suggested by the sampling table in Ronald Powell's text on research methods, a 45 percent proportion- ate, stratified random sample was selected which produced a final sample size of $214 .{ }^{19}$ Each name was numbered, and a computer program was used to generate the final sample list. The final sample represented library types as follows: 41.5 percent, academic; 41.1 percent, public; 10.7 percent, school; and 5.1 percent, private.

\section{Questionnaire Development}

It was necessary to develop a new questionnaire for this study because none was available that targeted this specific group of librarians nor the specific topic of discrimination in libraries. The pilot survey form consisted of twenty Likert-style questions where the respondent indicated agreement or disagreement by selecting a number between 1 (strongly agree) and 5 (strongly disagree). Most of the questions concerned issues related to job satisfaction (e.g., relationship with coworkers, feelings of personal accomplishment, and so on); however, some questions were included that dealt specifically with racism and discrimination.

Initially, the pilot survey was distributed to an audience attending a lecture on minority librarianship given by E. J. Josey on May 20, 1992, at Ohio Dominican College, in Columbus. This group was selected because the topic was deemed of interest to African American librarians and the turnout was expected to be significant. However, attendance was less than expected. Only thirty-four questionnaires were returned. The results were analyzed to check for any ambiguity in wording or interpretation of directions. Moreover, additional questions on job satisfaction were included. These were based on the job satisfaction questionnaire found in Andrew D. Szilagyi's Organizational Behavior and Performance. ${ }^{20}$ The final questionnaire consisted of three sections. The first section contained twenty-seven Likert scale attitudinal questions relating to job satisfaction and perceptions of discrimination. The second asked for demo- 


\begin{tabular}{|lrc|}
\hline \multicolumn{3}{|c|}{ Table 1 } \\
Demographic Responses* \\
\hline \hline Area of Work & $\mathrm{N}$ & Percentage \\
\hline Administration & 42 & 36 \\
Public Services & 67 & 57 \\
Technical Services & 6 & 5 \\
Other & 2 & 2 \\
Salary & $\mathrm{N}$ & Percentage \\
\hline Less than $\$ 20,000$ & 3 & 2 \\
\$20,000-\$30,000 & 24 & 20 \\
\$30,000-\$40,000 & 32 & 26 \\
\$40,000-\$60,000 & 53 & 43 \\
More than $\$ 60,000$ & 10 & 8 \\
Job Status & $\mathrm{N}$ & Percentage \\
\hline Full time & 120 & 98 \\
Part time & 2 & 2 \\
Professional & 118 & 97 \\
Support & 3 & 2 \\
Type of Library & $\mathrm{N}$ & Percentage \\
\hline Private & 4 & 3 \\
Academic & 54 & 43 \\
Public & 56 & 45 \\
School & 9 & 7 \\
Other & 1 & 1 \\
Size of Library & $\mathrm{N}$ & Percentage \\
\hline Large & 57 & 48 \\
Medium & 43 & 36 \\
Small & 19 & 16 \\
\hline * Percentages may not total $100 \%$ due to \\
rounding. & & \\
\hline
\end{tabular}

graphic information, both to aid in the development of a profile of the study participants and for comparison to previously studied relationships of demographics to job satisfaction. The information requested included current employment status, type of library, size of library, area of work, total years of library experience, salary, position status (e.g., fulltime/part-time, support/professional), education, and a check question to ensure that the respondent was African American. The third section asked respondents to define what they felt were the major issues facing African American librarians today. This section also provided space for additional comments, plus instructions on where and when to return the questionnaire. The final questionnaire was submitted to, and approved by, the Human Subject Review Board at Kent State University.

\section{Data Collection}

In April 1993, revised surveys were mailed to the sample of 214 individuals. A self-addressed, stamped envelope was enclosed with each survey to encourage its return and improve the response rate. The final survey was accompanied by a cover letter explaining the reason for the project and describing what steps would be taken to ensure anonymity. Also included were names, addresses, and telephone numbers of Kent State University faculty to contact with any questions or concerns about the study.

A deadline of May 19 was set for the first mailing, which produced 101 responses. In October, a second and final mailing resulted in twenty-three additional surveys. Thus, the final number of respondents totaled 124, for a response rate of 57 percent.

\section{Results}

Survey information was analyzed using the SAS (Statistical Analysis System) software program. Frequencies and percentages were computed for all questionnaire items using the SAS procedure PROC FREQ.

As table 1 reflects, 98 percent of the 124 respondents indicated they currently work in libraries: approximately 45 percent in public libraries, 43 percent in academic libraries, 7 percent in school libraries, and 3 percent in private libraries. These percentages closely match the type of library representation of the original sample. Most of the respondents were employed full-time (98\%), held a professional position (97\%), and had earned the Master of Library and Information Sci- 
ence degree (93\%). Most worked in public services $(57 \%)$, with the second largest group employed in administrative positions (36\%); only five percent worked in technical services. As to size of library, 48 percent of the respondents worked in a large library, 36 percent in a mediumsized library, and 16 percent in what they considered a small library.

Answers to a question concerning total years of library experience varied

\section{Relationships with coworkers, administration, and supervisors also were satisfactory for the majority of respondents.}

greatly, from one year to forty-one years. The median number of years of experience was eighteen, with approximately 50 percent of respondents falling in the range of eleven to twenty-two years of experience (i.e., interquartile range). Salary information was surprising considering the low pay generally associated with the profession. The largest group of respondents $(43 \%)$ reported salaries in the $\$ 40,000$ to $\$ 60,000$ range. As table 1 shows, almost 70 percent of the respondents made between $\$ 30,000$ and $\$ 60,000$.

Table 2 contains responses to the attitudinal questions. Questionnaires marked "strongly agree" or "agree" were categorized as agreement; those marked "disagree" or "strongly disagree" were categorized as disagreement. Respondents who marked the midpoint were categorized as neutral. As table 2 shows, most of the respondents (67\%) were generally satisfied with their jobs and agreed that their jobs gave them a sense of accomplishment (81\%). Relationships with coworkers, administration, and supervisors also were satisfactory for the majority of respondents. Only 15 percent indicated that they did not have a good relationship with their supervisor. Sixty-two percent agreed that their supervisor encouraged their professional growth, and 60 percent reported good relationships with administration. Fifty-six percent said that their coworkers made their jobs pleasant and that they were generally satisfied with coworker relationships (59\%). This positive relationship also extended to patrons in that 85 percent of the respondents felt that patrons responded positively to their efforts, with 59 percent disagreeing that patrons were reluctant to approach an African American staff member for assistance. Attitudes about patrons' respect were less certain, with only 45 percent disagreeing that clients do not respect their expertise as much as they do the expertise of their white counterparts.

Some of the attitudinal questions dealt with affirmative action, support for African American librarians, and observed discrimination. Fifty-six percent of the respondents felt that being an African American had not hindered their professional growth. Only six percent believed they had been denied access to continuing education opportunities because of race, with a slightly higher percent $(19 \%)$ believing they had been denied promotion because of race. Generally, respondents did not perceive affirmative action policies as being detrimental to their careers; 81 percent disagreed that affirmative action was a hindrance to professional growth. In terms of whether affirmative action had had any direct impact on their appointment to their present position, 43 percent felt it had not, 27 percent felt it had, and 30 percent were undecided.

The results suggest that libraries, for the most part, are complying with the law and that overt discriminatory practices have not directly affected professional growth of the responding librarians, yet only 32 percent of the respondents denied the presence of racial discrimination in their work environments. Seventy-six percent reported that their libraries did not have a mentoring program for minorities; 34 percent felt that their workplace lacked cultural diversity; and 32 percent agreed that the library administration was 


\begin{tabular}{|c|c|c|c|c|}
\hline \multicolumn{5}{|c|}{$\begin{array}{c}\text { Table } 2 \\
\text { Perceptions of Job Satisfaction and Discrimination }\end{array}$} \\
\hline & No. & Agree & Undecided & Disagree \\
\hline 1. My supervisor encourages my professional growth. & 121 & $62 \%$ & $21 \%$ & $17 \%$ \\
\hline 2. In general, I am satisfied with my job. & 123 & 67 & 26 & 7 \\
\hline 3. My co-workers make my job pleasant. & 124 & 56 & 31 & 13 \\
\hline 4. I never contemplate changing professions. & 123 & 35 & 28 & 27 \\
\hline $\begin{array}{l}\text { 5. I feel that Affirmative Action had a direct impact } \\
\text { on my appointment to my present position. }\end{array}$ & 123 & 27 & 30 & 43 \\
\hline $\begin{array}{l}\text { 6. I have observed racial discrimination in my work } \\
\text { environment. }\end{array}$ & 123 & 51 & 16 & 32 \\
\hline $\begin{array}{l}\text { 7. Clients do not respect my expertise as much as } \\
\text { they do my white colleagues' expertise. }\end{array}$ & 122 & 29 & 25 & 45 \\
\hline 8. My job gives me a sense of accomplishment. & 124 & 81 & 14 & 4 \\
\hline $\begin{array}{l}\text { 9. My library's administration is not sensitive to } \\
\text { the challenges facing African American librarians. }\end{array}$ & 123 & 32 & 20 & 47 \\
\hline 10. I have been denied promotions because of my race. & 123 & 19 & 18 & 63 \\
\hline $\begin{array}{l}\text { 11. My co-workers relate to me first, as a librarian and } \\
\text { secondly, as a Black librarian. }\end{array}$ & 120 & 42 & 32 & 25 \\
\hline 12. The workforce at my library is culturally diverse. & 123 & 36 & 30 & 34 \\
\hline 13. I do not have a good relationship with my supervisor. & 124 & 15 & 15 & 69 \\
\hline 14. My library has a mentoring program for minorities. & 118 & 10 & 14 & 76 \\
\hline $\begin{array}{l}\text { 15. Affirmative Action is a hindrance to my professional } \\
\text { growth. }\end{array}$ & 120 & 5 & 14 & 81 \\
\hline $\begin{array}{l}\text { 16. I am often asked for professional advice on } \\
\text { "non-ethnic" issues by my colleagues. }\end{array}$ & 121 & 54 & 27 & 19 \\
\hline $\begin{array}{l}\text { 17. I have been denied access to continuing education } \\
\text { opportunities because of my race. }\end{array}$ & 124 & 6 & 12 & 72 \\
\hline $\begin{array}{l}\text { 18. I am encouraged by my superiors to apply for } \\
\text { administrative positions. }\end{array}$ & 116 & 33 & 28 & 40 \\
\hline $\begin{array}{l}\text { 19. I often socialize with co-workers not in my } \\
\text { ethnic group. }\end{array}$ & 124 & 42 & 28 & 29 \\
\hline 20. I often think of searching for another job. & 124 & 28 & 27 & 44 \\
\hline 21. My job skills are being fully utilized. & 124 & 49 & 19 & 31 \\
\hline $\begin{array}{l}\text { 22. In general, I am satisfied with my relationship } \\
\text { with my co-workers. }\end{array}$ & 123 & 59 & 30 & 11 \\
\hline 23. I have a good relationship with the administration. & 124 & 60 & 25 & 15 \\
\hline 24. Patrons/clients respond positively to my efforts. & 123 & 85 & 11 & 3 \\
\hline $\begin{array}{l}\text { 25. Being an African American has not hindered my } \\
\text { professional growth. }\end{array}$ & 119 & 56 & 20 & 23 \\
\hline $\begin{array}{l}\text { 26. Patrons/clients in my library are reluctant to } \\
\text { approach an African American staff for assistance. }\end{array}$ & 123 & 16 & 24 & 59 \\
\hline 27. I intend to search for a new job in the near future. & 122 & 24 & 20 & 56 \\
\hline
\end{tabular}

insensitive to the challenges facing African American librarians, with 20 percent being undecided. Only 33 percent agreed that they are encouraged by their superiors to apply for administrative positions.
More important, only 42 percent said their coworkers related to them, first, as a librarian and, second, as a black librarian. These results, combined with the uncertainty about patrons' respect for their ex- 
pertise, suggest that the observed discrimination might be in the climate, support, and interpersonal relationships experienced in the workplace rather than in overt acts or practices.

Although 81 percent reported that their jobs gave them a sense of accomplishment, only 49 percent felt that their job

\section{Although 81 percent reported that their jobs gave them a sense of accomplishment, only 49 percent felt that their job skills were being fully utilized.}

skills were being fully utilized. It is true that 56 percent denied they intended to search for a new job in the near future, but only 44 percent denied they often think of searching for another job. There was far less certainty about changing professions, however. Thirty-five percent indicated they never contemplate changing professions and 27 percent indicated they do, with 28 percent being undecided.

Eighty-seven $(70 \%)$ of the participants responded to the section of the questionnaire asking them to list issues that are "important to African American librarians today." The top six concerns and their percentages are represented in table 3.

These results suggest that although African American respondents were generally satisfied with their jobs and, for the most part, with their coworker and supervisory relationships, they were less certain about staying with their current position or even in the profession as a whole. Because of this, it was decided to view contemplation of a job search (i.e., question 20) as another measure of satisfaction. Because the Likert scale questionnaire items were measured on the ordinal scale, Spearman correlations were computed to establish any significance between question 2 concerning general satisfaction with the job and other perceptions about the job, coworkers, discriminatory practices, and support represented in the remaining twenty-six at- titudinal questions. The SAS procedure PROC CORR was used to determine the correlations. Nonparametric equivalents of one-way analysis of variance were computed to examine potential relationships between general satisfaction and demographic items such as work area, size of library, type of library, job status, education, etc. Kruskal-Wallis tests were run using the SAS procedure PROC NPAR1WAY. These tests were repeated for question 20. Because of the number of relationships examined, a conservative alpha level of .001 was established for the study.

Although there was no significance between overall job satisfaction and the general employee-supervisor relationship (Q13), there was a moderate correlation between job satisfaction and having a supervisor who encourages professional growth $(\mathrm{Q} 1$, rho $=.49)$. In addition, having a good relationship with the administration is significantly related to overall job satisfaction (Q23, rho $=.46$ ). A tentative significant relationship existed between overall satisfaction and an administration that is sensitive to the challenges facing African American librarians $(Q 9$, rho $=-.33)$, meaning that those who are more satisfied perceive their administration as being sensitive to their needs.

Another area that shows some signifi-

\begin{tabular}{|c|c|}
\hline \multicolumn{2}{|c|}{$\begin{array}{c}\text { Table } 3 \\
\text { Issues concerning African } \\
\text { American Librarians } \\
\end{array}$} \\
\hline Issue & Percent \\
\hline $\begin{array}{l}\text { Lack of advancement and } \\
\text { promotion opportunities }\end{array}$ & $38 \%$ \\
\hline Racism and discrimination & 22 \\
\hline Recruitment and retention & 17 \\
\hline Salary & 15 \\
\hline $\begin{array}{l}\text { Need for more mentors and } \\
\text { role models }\end{array}$ & 13 \\
\hline $\begin{array}{l}\text { Participation and representation } \\
\text { in professional associations }\end{array}$ & 10 \\
\hline
\end{tabular}


cance in determining job satisfaction is the relationship with coworkers $(\mathrm{Q} 22$, rho $=$ .30). Results show a moderate significance between job satisfaction and having coworkers who make the job "pleasant" $(\mathrm{Q} 3$, rho $=.43)$. Being able to socialize with non-African American librarians also was of moderate significance in determining job satisfaction $(\mathrm{Q} 19$, rho $=.38)$.

The strongest significant factor to overall job satisfaction was related to the librarian's individual feeling of accomplishment (Q8, rho = .54). A slight significance existed between satisfaction and the perception that one's job skills are being fully utilized $(\mathrm{Q} 21$, rho = .39).

Test results show a moderate correlation between job satisfaction and the intent to search for a new job $(\mathrm{Q} 20$, rho $=-.40)$, meaning that those who are satisfied are unlikely to do so. This correlation is consistent with that of those who are contemplating changing professions $(\mathrm{Q} 4$, rho $=.43)$. Generally, librarians who are satisfied in their work are not planning to search for a job in the near future $(\mathrm{Q} 27$, rho $=-.35)$.

No significant correlation was found to exist between overall job satisfaction and Affirmative Action policies. Test results also indicate no significant relationship between overall job satisfaction and overt discrimination, relationships with clients, or lack of promotional opportunities. Other factors shown not to have significant correlation include: cultural diversity of the workplace, existence of a mentoring program, access to continuing education opportunities, and encouragement to apply for administrative positions.

As previously mentioned, thinking about other employment opportunities (Q20) also might be viewed as a measure of satisfaction with the current job position. As already noted, those who are satisfied with their job do not contemplate looking for another one $(\mathrm{Q} 2$, rho $=-.40)$. An interesting fact, however, was that those who are considering looking for another job also are thinking of leaving the profession $(\mathrm{Q} 4$, rho $=-.43)$, and they are considering taking on a job search in the near future $(\mathrm{Q} 27$, rho $=.65)$. Results also show a moderate significance between the desire for a new job and observed racial discrimination in the workplace $(Q 6$, rho = .36). There existed a slight significant correlation between the intent to search for a new job and the perception of a lack of sensitivity to the challenges facing African American librarians on the part of the administration $(Q 9$, rho

\section{No significant correlation was found to exist between overall job satisfac- tion and Affirmative Action policies.}

$=.32$ ), the nature of the client relationship $(\mathrm{Q} 7$, rho = .33), and the librarian's sense of accomplishment (Q8, rho = -.35). In addition, there was a slight significance between the intent to search for a new job and the feeling that being an African American is a hinderance to professional growth $(\mathrm{Q} 25$, rho $=-.34)$.

Kruskal-Wallis tests were run to test for any significant relationship between the two satisfaction measures (Q2 and Q20) and demographic factors. No significant relationship was found at the .001 level.

\section{Conclusion}

Although the data show no significant correlation between job satisfaction and perceptions of racism and discrimination, two specific aspects of this study require closer examination. First, respondents to the survey listed racism and discrimination as the second most important issue facing African American librarians today (see table 3). Second, 69.3 percent of the participants responded to the comments section of the questionnaire. The vast majority of these comments were positive. They "loved the idea" of this study. They felt that "it was about time" that someone looked into it in detail. They "hoped to see the results published." Some even included their name and address so that they 
could be informed of the results in the event the data were not published. Only one respondent chided the researcher for putting too much emphasis on "blackness," feeling that this did more harm than good to professional African American librarians. This researcher disagrees.

So one might ask, if racism and discrimination are issues of major concern among this selective population, why is there so little statistical significance between these factors and overall job satisfaction? Although there may be no scientific explanation to this disparity, an opinion can be supplied based on personal observation. Racism is intrinsic to this society. As an African American, this author is reminded of its existence every time she looks in the mirror or ventures out of her home. The reality is that equal opportunity and fair treatment can be legislated but attitudes cannot.

Racism is such an integral part of our environment that, by itself, it is not a significant and recognizable determinant of job satisfaction or dissatisfaction. So, where African American librarians may agree that racist attitudes and practices need to be addressed within the profession, the existence of racism alone is not the primary source of job dissatisfaction.

Second, this study indicates a moderate relationship between the intent to search for a new job and perceived discrimination on the job. The group that showed a correlation between these factors also perceived a lack of administrative sensitivity to the challenges they face, along with the feeling that being an African American is a hinderance to their professional growth.

Of particular concern to this author is the moderately significant relationship between the intent to search for a new job and the consideration of leaving the profession altogether. Any loss of African Americans to the library profession is a great one.

Jan S. Squire noted that "it is apparent from the lack of literature that dealt with the job satisfaction of ethnic minority librarians that there is a need for research to be conducted in order to examine this area more fully." ${ }^{21}$ It is hoped that this study is just the beginning.

\section{Notes}

1. E. J. Josey, ed., The Black Librarian in America (Metuchen, N.J.: Scarecrow Pr., 1970); -, What Black Librarians Are Saying (Metuchen, N.J.: Scarecrow Pr., 1972); E. J. Josey and Kenneth E. Peeples, eds., Opportunities for Minorities in Librarianship (Metuchen, N.J.: Scarecrow Pr., 1977).

2. George P. D'Elia, "The Determinants of Job Satisfaction among Beginning Librarians," Library Quarterly 49 (July 1979): 283.

3. Beverly P. Lynch and Jo Ann Verdin, "Job Satisfaction in Libraries: A Replication," Library Quarterly 57 (Apr. 1987): 198.

4. Susanne P. Wahba, "Job Satisfaction of Librarians: A Comparison between Men and Women," College E Research Libraries 36 (Jan. 1975): 46.

5. Mohammad H. Mirfakhrai, "Correlates of Job Satisfaction among Academic Librarians in the United States," Journal of Library Administration 14, no. 1 (1991): 124.

6. D'Elia, "The Determinants of Job Satisfaction among Beginning Librarians," 300.

7. William J. Vaughn and J. D. Dunn, "A Study of Job Satisfaction in Six University Libraries," College \& Research Libraries 35 (May 1974): 163.

8. Edward W. Jones Jr., "Black Managers: The Dream Deferred," Harvard Business Review 64 (May-June 1986): 88.

9. Ibid., 85 .

10. Ibid., 92 .

11. "U.C./Irvine Library Director Resigns during Bias Investigation," American Libraries 22 (May 1991): 374.

12. Gloria Leonard, "Bias Busting: Valuing Diversity in the Workplace," Library Administration $\mathcal{E}$ Management 5 (fall 1991): 205. 640.

13. "Court Award to Black Employees Cut by $\$ 600,000, "$ American Libraries 19 (Sept. 1988): 
14. Margaret Collins, "Employment Discrimination Faced by Black Librarians," in The Black Librarian in America Revisited, ed. E. J. Josey (Metuchen, N.J.: Scarecrow Pr., 1994), 256.

15. R. Roosevelt Thomas Jr., "From Affirmative Action to Affirming Diversity," Harvard Business Review 68 (Mar.-Apr. 1990): 108.

16. Patrick Hall, "Against Our Best Interests: An Ambivalent View of Affirmative Action," American Libraries 22 (Oct. 1991): 899.

17. Leigh Estabrook, Chloe Bird, and Frederick L. Gilmore, "Job Satisfaction: Does Automation Make a Difference?" Journal of Library Administration 13, no. 1-2 (1990): 183.

18. Hall, "Yassah! I's the Reference Librarian!" American Libraries 19 (Nov. 1988): 900.

19. Ronald Powell, Basic Research Methods for Librarians (Norwood, N.J.: Ablex, 1991), 75.

20. Andrew D. Szilagyi, Organizational Behavior and Performance (Glenview, Ill.: Scot, Foresman, 1987), 702.

21. Jan S. Squire, "Job Satisfaction and the Ethnic Minority Librarian," Library Administration $\mathcal{E}$ Management 5 (fall 1991): 201. 